\title{
Chapter 10 \\ Challenging Misconceptions: Danish Civil Society in Times of Crisis
}

\author{
Martin Bak Jørgensen and Daniel Rosengren Olsen
}

\subsection{Understanding Crises in the Danish Context}

The stability of global capitalism has been challenged successively since the turn of the last millennium. It was initiated by the burst of the "dot.com bubble", massive demonstrations against the current globalization regime (the anti-globalization movements, see Graeber 2002) and the shocking images of the World Trade Center in flames. ${ }^{1}$ Not long after these events, the entire system of global finance came tumbling down during the "Financial Crisis" that brought the entire machinery to a grinding halt and demanded enormous amounts of "quantitative easing" to resume operations. In the European context, the financial crisis precipitated several further crises, including a range of "debt crisis" (Greece, Italy, Malta, etc.) potential and eventual "Exits" (Greece, UK), and eventually a crisis of the entire European Unionization project, concomitant with the "refugee crisis" mounting as a consequence of the Syrian civil war - and, not to forget; the burgeoning climate crisis.

This leads us to one of the larger questions of contemporary social movements. The "traditional stance" on social movements, with point of departure in Marxian class analyses, were challenges with the emergence of "New Social Movements"

\footnotetext{
${ }^{1}$ While symbolic of many things, the Twin Towers were the iconic symbols of world commerce; a pride of the Trading City of New York, thus their destruction may be interpreted as symbolic representation of an attack on the entire global capitalist system, and equally indicative of the system's instability and fragility when faced with shocks (see also Beck's [2006] analyses in this regard).
}

\footnotetext{
M. B. Jørgensen ( $\square)$

Department of Culture and Learning, Aalborg University, Aalborg, Denmark

e-mail: martinjo@hum.aau.dk

D. R. Olsen

Department of Communication and Psychology, Aalborg University, Aalborg, Denmark e-mail: rosengren@hum.aau.dk
} 
(NSM) in the late twentieth century, which questions the central concept of Marxian analysis that "capital", "labor", and "class" could remain undifferentiated and function as the major frame of social movement and class-based resistance to capitalist exploitation (Dubet 1994; Offe 1985; Welton 1993). The change has often been structurally identified with a shift to "post-industrialization" in Western societies, starting from the early 1960s. The NSMs are structurally seen as aligned with middle-class citizens rather than the lower classes and oriented towards personal and cultural change (lifestyles and identities) rather than formal policy changes or "regime changes" as in the classical Marxist revolutionary theory (Melucci 1980).

The emergence has led to a series of debates over theoretical accuracy in terms of description, but equally in the normative implications of the various approaches to social movement analysis. A current schism centers on the left's "abandonment of the poor" in favor of the NSM concern with "the personal" rather than with the plight of the underclasses, which may have provided an important impetus for the realignment between nationalists, conservatives, and the lower classes (Piketty 2018; Jørgensen 2016). Importantly, the NSMs of the right (Generation Identity, the "ALT-Right", Fortress Europe, etc.) illustrate the diversity and complexity of the field of the identity-oriented new movements and the cleavages between their outlooks on future trajectories.

Taking the contemporary situation into consideration, it is perhaps not too surprising that people may find the situation perplexing and consequently that we see a plethora of initiatives pointing in different directions. In this article, however, we focus on the confluence between a contemporary Danish NSM, Venligboerne, and their position within the larger "refugee solidarity movement". Using Alan Sears' concept infrastructures of dissent, we argue that the contemporary situation requires a diverse range of social movement activity, relying on both traditional and "new" approaches to social movement development and "political praxes", ranging from protest activity to everyday engagements with repressed subjectivities ("everyday activism"). We attempt to illustrate how Venligboerne provide a "piece" in the complex puzzle of contemporary social movement activity in the area of migration, and how we can view their emphasis on "identity and lifestyle" as supportive of the larger movements rather than a hindrance.

\subsubsection{Research Approach}

Inspired by the notion of infrastructure of dissent, we analyze our case, Venligboerne, from two distinct angles: Firstly, by attempting to disseminate how this particular CSO has differentiated itself from other organizations in the field, and secondly, by analyzing the organization as a community of learning. The study relies on a mixed-methods approach to data collection based on participatory research, interviews and secondary data collection. It is a qualitative, exploratory study which aims to describe and understand this particular CSO in a specific 
context rather than aiming to build invariant models for social movements (Tilly 1995, p. 1596).

Our research is situated in the Danish context during the peak of the refugee (reception) crisis (2015-2018), focusing on the relationship between the organizational characteristics, and the context of events in which the organization found itself. We have opted for a mix of descriptive approaches covering both participation (online and offline), as well as the collection of secondary data from various sources such as newspapers and online forums. We have more actively engaged with the refugee solidarity network as well, from which we have also been able to acquire information and insights into the overall movement (albeit from a partial perspective).

We chose Venligboerne as a case for several reasons. Primarily because of the movement's emergence in relation to the refugee (reception) crisis and its popularity, having mobilized more than 150,000 members in the extensive range of Facebook groups (Toubøl 2015), which earned the movement national recognition and presence across the country. The case is also significant because of its distinct approach that has differentiated Venligboerne from other CSOs in the refugee solidarity movement. Additionally, the initiative differs from most other CSOs within the refugee solidarity network; relying on an "a political" approach, heterogeneous activities, informal organization, and other characteristics, which, we argue, have allowed the movement to situate itself as a an important "mediator" within the very diverse range of organizations that make up the refugee solidarity network (FengerGrøndahl 2016; Nygaard 2017; Toubøl 2017).

\subsection{Civil Society and Infrastructures of Dissent}

We understand dissent as “... social and political questioning (not just [...] mere critique or a need for palliative reforms), [...] undoing consensus and rendering excluded actors and struggles visible” (Jørgensen and Agustín 2015, p. 14). From this view, dissent assumes relevance as experiences opposed to a dominant order to render new actors, struggles and ways of organizing visible. Dissent commonly evokes mental imaginaries of militant forms of action; however, we see dissent also as the everyday forms of resistance and politics taking place in the "refugees welcome" movement as well as the development of practices of sharing, caring and learning.

In his book The Next New Left, Alan Sears (2014) coins the notion infrastructures of dissent. Such infrastructures, according to him, provide social movements with four essential capacities: collective memory; collective dreams; collective learning; and capacity for solidarity. Sears argues that "[i]nfrastructures of dissent can be defined as the means through which activists develop political communities capable of learning, communicating and mobilizing together" and continues by arguing that infrastructures of dissent "[are] a crucial feature of popular mobilization, providing 
the basic connections that underlie even apparently spontaneous protest actions" (Sears 2014, p. 2). Hence, when we analyze Venligboerne, we seek to identify how the organization provides the organizational infrastructure needed to support various forms of dissent.

In the context of this volume, we view dissent as intricately related to the "hope" for a better future beyond the bleak political situation that Europe (and hereby Denmark) has found itself in. It is a rejection of both the apathy and the pernicious ethnocentric nostalgias of contemporary nationalistic ideologies. Hope for a better future is not merely a positive outlook on things as in a naïve optimism that "everything will be alright". To the contrary, hope indicates a belief in the value and expediency of activities in the present: that a better future can be created with actions implemented today. Hope, in this sense, is also required to combat lethargy, pessimism, and even resignation to the reigning ideological powers. In this regard, we see infrastructures of dissent as channels for a politics of hope. Sears argues infrastructures of dissent "enable people to develop collective dreams, to envision a better world, which provides a tremendous motivator and important moral compass" (Sears 2014, p. 18).

In Sears' framework, the infrastructure of dissent entails the capacity for solidarity as an integral component. Following Rick Fantasia, Sears does not regard solidarity as an automatic reaction to injustice, but rather something that must be cultivated (Sears 2014, p. 21). In other words, while individuals may sympathize intuitively with say refugees, organizational infrastructures are required to enable solidarity as effective praxis. Hence sympathy will not be useful if it is not translated into practical action. We regard solidarity as a relational practice; solidarity is contentious; emerges strongly in moments or conjunctures; is generative of political subjectivities and collective identities; entails alliance building among diverse actors; is inventive of new imaginaries; is situated in space and time (Agustín and Jørgensen 2016, 2019). In this chapter, we focus especially on the aspect of alliance building, which we understand in relation to Sears' capacity for solidarity. Alliance building is a crucial aspect of solidarity. The heterogeneity of political actors can only converge in a complex social composition if they manage to identify the diverse oppressive effects of the dominant order. This plurality generates a relation of solidarity that benefits all parties as the possibility of challenging the system is enhanced. Thus, solidarity becomes a driving force in promoting social change from civil society (Agustín and Jørgensen 2016). Solidarity cannot precede political actors nor can political actors impose their identities or interests upon others. Hence, when considering alliances between civil society and immigrants, the question is not identitarian but about how different political actors converge in ongoing social struggles to undo political closure (Agustín and Jørgensen 2016).

Following this approach, the activities undertaken in civil society are predicated on a consolidation of the differences that emerge within civil society itself. Conflictual situations cannot be reduced to "the state versus its others" but are equally present within civil society and must be resolved through other means of settlement (or the state will prove itself an inescapable necessity). This corresponds to the conceptualization of fluid relations between state and civil society, and 
underscores the importance of developing appropriate ways of solving such disputes without resorting to state interference or other means of force. Accordingly, we do not view civil society as a unitary constellation, but as a bricolage of various elements that at times come together as one, but at other times fragment in a range of different positions. Civil society, as such, has both propitious and deleterious components (Carothers 1999) but cannot be viewed as a uniform or integrated entity. In spite of this diversity and adversity, the objective is to advance better ways of living as communities and societies; mitigating means of oppression, violence, inequality, etc. Employing the idea of infrastructure of dissent makes it possible to analyze the contours of politics of hope articulated here.

\subsection{Venligboerne: A Brief Summary}

The Venligbo movement began in April 2013, with a local initiative to improve the wellbeing of residents in the small town of Hjørring in northern Jutland, Denmark. The founder, Merete Bonde Pilgaard, saw kindness and hospitality as a way to transform people's lives in a positive direction, not only because it would be nice if people were friendlier to one another, but because, she argued, being friendly to others is also transformative for the person that changes her own outlook on the world. She argued that when people stopped thinking in negative terms about others, criticizing and problematizing other people's identities, actions, beliefs, etc., they became happier themselves (TV2Nord 2017). Kindness, curiosity and respect for diversity constitute the ideological foundation of the Venligbo movement. These values are also supplemented by the advice to meet the other face-to-face, to tell and listen to stories and take the time to be with the other person. In a very simple formulation, Merete Pilgaard states that her mission with the organization was to "train people in staying kind, even when others are not being kind" (Mortensen and Lumholt 2018). Beyond these values, we can observe how the initial ideas have branched into a wide range of activities that characterize the movement today:

- Providing various forms of practical assistance such as legal aid, medical support, language training, job-seeking assistance, transportation, everyday donations, including raising funding for family reunifications, etc.

- Creating broad alliances between experienced activists and people new to solidarity work, as well as across a wide range of activist approaches and focus areas.

- Making the problems of the asylum process and integration into Danish society visible.

- Insisting on a humanitarian approach different from the exclusivist approach taken by the state. The movement also articulates the commonalities between people; refugees and Danes alike.

- Emphasizing the importance of personal stories, urging people to listen openly and engage with the experiences of the other, regardless of who this person is, 
even seeking out others that are different from oneself to possibly find stories that are different from one's own.

The movement has been characterized as a reinvigorated wave of Danish NSMs that has followed in the wake of the great recession. These initiatives are in many ways similar to the NSMs of the late twentieth century, but after a period of hiatus, Danish society has seen an increasing focus and emphasis on these new citizendriven initiatives (Regeringen 2014), which are often promoted as precursors of future societal arrangements (Lumholt 2019; Mortensen and Lumholt 2018; Regeringen 2010).

Although the movement focuses on everyday encounters between people, the numerous Venligbo Facebook groups have become an important vehicle for the spread of the movement, with each municipal faction usually creating their own online forum as subgroups under the overall movement, and many other groups for the organization of specific activities such as donations, discussions or local activities. While Facebook organizing is not unusual for social movements and civil society organizations, it is, however, relevant to observe that the groups have mostly been used for internal organizational and activity coordination with most of the groups being "closed" to non-members (i.e. not used for promoting ideas, policies, agendas, and so on). Besides the Facebook groups, several other initiatives have also been launched such as Venligbo cafés that have been established and run entirely by volunteers, festive events (such as Café Venlig På Tvars in Aalborg), help with learning Danish and translations, help to find work, fundraisers, and much more.

\subsubsection{Organizational Structure}

The Venligbo movement features traits of both formal and informal organizational structure; however, the general structure of the movement is much closer to informal social movement organization (SMO) than formal movement organization (Staggenborg 1988; Willems and Jegger 2012). The movement has no formal leadership, and founder of the movement Merete Bonde Pilgaard has rarely challenged the conduct of local factions, albeit some controversy has existed around the interpretation of the movement values. There is no centralized control or bureaucratized decision-making process and no formalized divisions of labor, although many of the factions do establish some degrees of formalization to handle organizational management on an everyday basis. Especially larger projects such as the Venligbo cafés, funds, events, and so on, have necessitated some degree of organizational formalization. However, this formalization is only attributable to subunits of the movement, not to movement-level organization and functioning. Neither does it apply to most movement organizing, which is primarily effectuated through ad hoc problem solving. The overall organizational management centers on the value foundation of the movement and a small "daily management board", "Friendly Guides" 
(Venligboerne n.d.). This form of social movement organization is broadly similar to the "new social movements" (NSM) theories emphasizing identity and personal transformations as the primary guide for movement activities (Fominaya 2010; Offe 1985). This informal, value-based approach to movement organizing has been a fecund ground for initiatives that are based on the underlying movement values and which accord with the movements" overall identity, but which are not "caused" or predetermined by these identity formulations. This organizational form has supported the innovative character of civil society and provided possibilities for individuals to express themselves and act in creative ways.

Initially, there were no attempts to create an institutionalized way of governing the adherence to the organizational value foundation. However, in the spring of 2015, Pilgaard initiated the "Friendly Guides" to administer the rapid expansion of the movement and its subunits, which illustrates, perhaps, the most prominent change towards formalization on behalf of the overall movement. Importantly, this expansion escalated as the Venligbo idea was combined with helping refugees in the spring of 2015 when the many refugees fleeing Syria began to reach Denmark. Pilgaard met with Mads Nygaard who, at the time, worked in the newly reopened Asylum Center in Hjørring. They agreed that the Venligbo ideology would be a good idea.

The "hands-off approach" was also challenged during a conflict in 2016 over the approach to politics within the movement and by a deviant local group on the island Fyn that had adopted the name Venligboerne, but which most other factions agreed was not operating in accordance with the movement's identity, values, or goals (Fenger-Grøndahl 2016). However, in spite of the general agreement against this particular Facebook group, the incident did spark a persistent internal debate around organizational leadership, management, and general principles, which created fault lines between various positions within the movement, and which, to some extent, remain unresolved.

\subsubsection{Network, Alliances and the Refugee Solidarity Movement}

The Venligbo movement has extensive links within the Danish refugee solidarity movement and beyond (Agustín and Jørgensen 2019). These links (collaborations, strategies, and ideological alliances) and practices of solidarity are part of the larger infrastructure of dissent which has been the basis for the ongoing solidarity mobilizations spanning the entirety of the refugee solidarity movement. This infrastructure is comprised of solidarity practices and networks of the 1980s, 1990s and 2000s (Agustín and Jørgensen 2019; Toubøl 2015), to which Venligboerne adds a relatively new component. The development of the refugee solidarity movement in the past has not been as extensive as the scope we witness today, and it may be argued that this is the first time in contemporary history that Denmark has experienced the 
emergence of a loosely affiliated, countrywide network mobilizing around issues of migration, nationality, and migration policies. Nevertheless, the prior experiences and infrastructures partake in the shaping of the collective memory and praxes and guide the building up of the network today.

The existing network consists of a range of different organizations and initiatives that vary between highly formalized and occasionally state-aligned initiatives (i.e. NGOs such as Danish Refugee Council and Danish Red Cross) to local and highly informal networks that are further removed from the state apparatus and, in some cases, opposed to the state (i.e. anarchist groupings). Politics can be a highly divisive aspect in this regard, even when we consider a relatively aligned range of actors (i.e. the refugee solidarity movement as a whole), that may create cleavages between individuals or groups because their ideological backgrounds, identities, worldviews, repertories of contention, and so on, are incongruent. Some, for instance, might see NGOs as inefficient giants squandering money on expensive staff and PR campaigns, while others may see the direct-action tactics of small political initiatives as "deviant". What we want to emphasize, however, is the possibility of cooperation with a very broad variety of initiatives, as illustrated by Venligboerne, creating new alliances between many different organizations, likely, but not exclusively, as a consequence of their "apolitical approach" to everyday activism ("apolitical" understood as non-Party affiliation and avowedly not policy-oriented). This cooperation has augmented the infrastructures of dissent and provided new avenues for activist entrance to the refugee solidarity movement (Rutland 2013; Toubø1 2017).

Within the network, Venligboerne connect with numerous types of organizations and initiatives: from municipalities and local political parties to NGOs, political movements, and everything in between. These connections exist, not only through member overlaps but also through collaborations and mutual support in various activities. Thus, in spite of a great diversity within the overall network, Venligboerne have been able to position themselves as a significant node with connections permeating broadly across the entire network. This is significant to illustrating the diversity of the network actors and the need for "linking" between organizations that might otherwise not cooperate. Our proposition here is that Venligboerne occupy exactly this position as a linking organization between the range of actors in the overall movement.

It may be argued that this position has emerged as a consequence of interactions between Venligboerne and the existing refugee solidarity movement, rather than being merely a strategic self-positioning. The movement itself has certainly developed because of its contact with other organizations and individuals in the refugee solidarity movement, not least has this been an impetus for the divide between the "political" and "non-political" factions of the movement. Pilgaard has definitely never articulated a strategy for the movement in terms of its alignment with other organizations or individuals within the broader refugee solidarity movement. Such considerations were only articulated as the movement began to grow, and more politically engaged activists emerged as prominent voices from "inside" the Venligbo movement. 
While refugees and the cooperation with new citizens play a large and important role in Venligboerne, the scope of the movement's activities is much wider. Thus, for instance, we also see a close cooperation with other civil society organizations such as Nastehjaelperne (helping your next one, as in the person in your proximity) or Sabaah to help respectively the jobless or the LGBT communities of ethnic minorities. The collaboration with Nastehjcelperne provides an illustrative example of how solidarity shapes alliance building by identifying commonalities and common struggles. Nastehjaelperne have organized a network for "reform-stricken" people. Many of the organization's members are themselves affected by the new labor market and social policy reforms that have tightened legislation on social services and compensations for people out of work. Within Nastehjaelperne, people help one another and together oppose the recent reforms, particularly focusing on how the contemporary legislation forces people with reduced capacities to work. They also seek to bridge the gap between "the working people" and the "nonworking people" (on social benefits or compensations) because a consequence of the current neo-liberal turn has been a stigmatization of people outside the labor market. Nastehjalperne and Venligboerne connect struggles through not seeing migrants and refugees as competitors for social services, but as people who are equally deserving of social rights (Thomsen and Jørgensen 2013). Returning to Venligboerne, if we look at the mantra of the CSO "to meet others with curiosity and respect", this outlook underlies the elementary praxes of the organization: the engagement with the other in a constructive and non-prejudiced way, regardless of who the other is.

The "linking" between diverse groups of the refugee solidarity network, and even with organizations from many other areas, is important in terms of the general political landscapes as well, since it creates possibilities for broader alliances between a range of actors, movements, and groups along the same lines that Offe (1985) discusses as an important question for NSM and their alliances with the traditional left-right political spectrum. This can be seen in the contemporary labor market debates and refugee policies, in which refugees are commonly portrayed as "stealing the jobs of the autochthonous population", or worse still: the welfare (Jørgensen and Thomsen 2016). It is politically expedient for nationalists and conservatives to convince unemployed and underemployed workers that refugees are the cause of their predicaments. Consequently, from a progressive perspective, the building of alliances between these groups is a necessary step to avoid collusion between conservatives, precarious workers and various factions of nationalists. Whether such alliances are established as explicitly party-political alliances or through informal civil society collaborations, activities or events is not of great import, since the development of infrastructures of dissent takes both time and a broad variety of initiatives. 


\subsubsection{Civil Society and Communities of Learning}

In various movements, for instance self-help movements or religious movements, the target of the movement is not an external entity that is asked to "deliver changes" but rather the members of the movement itself. Consequently, these movements are more "inward-looking" and focus on their own practices, activities, and so on, rather than looking to an external entity (i.e. the state) to ask for change. Some researchers have criticized these forms of movements (particularly the self-help movements), arguing that they are "retreating from democratic participation" or lacking in terms of engagement with the wider society (Baumann 1999; Marcello and Perucci 2000). However, other scholars see more potential for these kinds of groups to play a part in the general public sphere and democratic life (Anheier 2004; Giddens 1991; Welton 1993). Looking at Venligboerne, we argue there is a positive consequence of such participation and involvement in the CSO work.

Primarily, the movement addresses an interpersonal issue. If we return to the three central pillars of the organization (kindness, curiosity, and respect for diversity), these constitute the central framing of the movement and identify its primary targets and methods. The core pillars address different sides of the same problematic: meeting the other, whoever this person may be. In some cases, the other is a Dane, in other cases a refugee. Following the logic of Venligboerne, this categorical distinction essentially makes no difference as to how one should relate to the other. However, if we reverse the logic of the three pillars, we see that the issue all three pillars address is a deficiency in how we engage with the other: a lack of curiosity, a lack of respect, and a lack of friendliness. Instead, we often meet others with suspicion or negativity: we talk "behind their backs", and we do not trust their actions and initiatives (TV2Nord 2017). Pilgaard argues that by changing this negative approach to others, we will improve not only their lives, but also our own. Consequently, the movement promises betterment through self-improvement or "lifestyle changes", and the central tenet of the movement is the members' own struggle to improve the way they meet the other, whoever the other is. However, while this orientation appears as an inward gaze, the consequence is not a distancing, or isolation, from the rest of society, the result is rather the opposite; a stronger connection with the larger society and, more importantly, areas of society that have been either marginalized, suppressed or isolated (refugees but also recipients of social support and other stigmatized groups such as the LGBT+ community). Sears argues that the infrastructure of dissent provides avenues for collective learning to help people develop an understanding of how the world works and how it might be changed (2014). Moreover, collective learning provides the means for developing a profound political culture, which we, in the context of this book, link to the idea of a politics of hope: hope cultivated and driven through communities of learning.

Welton (1993) views new social movements (NSM) as sites of adult learning, arguing that these movements are particularly well-suited sites for such activities, and that we should view the NSMs as spaces for learning about new subjectivities, social justice, solidarities, civic engagement, and personal relations to a wider 
society (Kilgore 1999). This includes the cultivation of emancipatory praxes, and in spite of the espoused "individualism" of NSMs, Welton argues that introspection and personal fulfillment "cannot be separated from collective action" (Welton 1993). The personal engagement with the other thus becomes a "first step" towards renewal of political imagination and accompanying praxes of dissent.

In a Deweyan sense, this learning process is based on the educational content of experiential and cooperative engagement with as broad and diverse a variety of social life as possible (Dewey 1916). In the case of Venligboerne (and similar organizations), we see how CSOs can contribute constructively to supporting engagement between groups that may otherwise tend to be isolated from each other, even if they are geographically situated close together. As in Dewey's experiential learning, the organization facilitates a personal encounter and experience with a social reality that may otherwise seem distant or unrelated to the individual, thus allowing for people of different groups to explore commonalities of oppression and for new solidarities to emerge. We must also note that besides the case of refugees, the SO supports a broad range of interaction between people from all walks of life in shared endeavors to solve everyday problems and establish collective projects and visions for the future, which is exemplary of the Deweyan ideal of social development and captured in his distinction of great societies from great communities (Dewey 1938).

The negative case (usually the result of a prolonged voluntary or involuntary separation between groups) can be exemplified with youth criminality, gangs, social control, racist organizations, and the like, which are all examples of collusions around other social objectives and through other forms of organization. These are examples of social learning and civil society organization all the same, but we see how they are not examples of positive forms of collective organization. They do not contribute to the development of good sense because they are isolated from most of society, because they do not collaborate with others, because their values are exclusionary, and because their practices are mostly self-serving.

The daily engagement with others helps to develop new, shared imaginations and collective visions for a different future than the hegemonic discourses of contemporary society, which have been borne by the politics of fear (outlined by Hellström et al., Chap. 1 in this volume). Instead of pandering to these xenophobic discourses, Venligboerne provide a space for challenging contemporary nostalgias and fears through an open engagement with the "Other"; experiment with the possibilities for conviviality, collaboration, and solidarity. Thus, this example illustrates how hope can be cultivated, even in dire situations such as during the compounding crises that Europe faced following the great recession.

When we relate these observations to the contemporary Danish society, an important insight can be gleaned from the chosen case that may shed some light on Dewey's somewhat forgotten insight of democracy and education. His educational approach reminds us that a politics for democracy must be founded on an organizational approach that supports a broad and diverse engagement between different forms of life (Dewey 1916). Civil society's qualities rest on the normative insight that they should be conducive to such activity that widens and extends the interaction between all citizens as far as possible, and at the same time do so in a way that 
emphasizes egalitarianism and mutualism, as in the case of Venligboerne (see also Freire 1970). In times of crisis, this function becomes particularly pertinent: the cultivation of hope and development of collective imagination and ideas (Haiven and Khasnabish 2016) are crucial to the infrastructures of dissent and collective abilities to challenge ideological hegemonies and political closures. Similarly, we may also point to the importance of individual agency and empowerment, which is also part of the development of alternative politics. While class-based movements emphasize the political power of a collective group in unison, NSMs tend to emphasize the power of the individual to promote an active self-invested participation in political problems. Both approaches are integral to solving many of the complex problems faced in times of great challenges and uncertainty.

\subsubsection{Infrastructure of Dissent in Times of Change and Insecurity}

Learning in social movements has been addressed from a variety of perspectives, but in this chapter we want to primarily connect it with the idea of infrastructures of dissent in a time of large-scale changes and insecurity. As we mentioned in the introduction, the world economy and global capitalist system tremble; the twentieth century global political order is reversing; nationalism, ethnocentrism, and various nostalgias are on the rise along with rampant inequality. But what are the perspectives for contemporary progressive social movements?

Thinking in terms of infrastructures of dissent is useful to move beyond the traditional perspectives of class-based social movements that easily overlook both the diversity of political subjectivities as well as the necessity for developing intraorganizational collaboration, trust, resource sharing, planning, visions, and much more. The case of Venligboerne, we hope, illustrates how a CSO may appropriately position itself, not necessarily in the forefront of protest, yet still at the heart of progressive development.

To "learn", in this respect, is not associated with the formalized idea of didactic curricula and teaching methods, but can be understood with Alain Touraine's theory of the subject (Dubet 1994; Rutland 2013) emphasizing the movement of the individual through social space as a process of "work on the self", meaning an individual development, which is not reducible to some "knowledge of facts", but which includes emotions, ideas, visions, ideology, resources and subjectivity, shaping the individual's sense of self in social space though without giving up the recognition of a social space that equally influences the movement of the individual.

This view is important to avoid fracturing among progressives and to strengthen alliances between different groups (such as refugees, workers, the jobless, etc.), to establish spaces of social learning and development which together constitute the infrastructures of dissent that may constitute the support needed for progressive forces of the twenty-first century. 


\subsection{Conclusions}

The Marxist philosopher Ernst Bloch wrote about utopia and hope in the first part of the twentieth century. He rejected the cultural pessimism of his peers (for instance Adorno) and insisted on the transformative power of political action by the working class and the new social movements. A particularly compelling statement stemming from The Principle of Hope (a three-volume piece) written between 1938 and 1947 goes: "The most tragic form of loss isn't the loss of security; it's the loss of the capacity to imagine that things could be different" (here from the 1986 edition). Although not carrying the same optimism as Bloch, Sears also expresses hope of political transformation (in his case for the reinvigoration of the left). Hope is action, and action for him is located within the framework of the infrastructure of dissent. This provides the means to develop the capacity to make connections and develop knowledge out of collective experience and to enhance the ability to work strategically as mobilizations evolve (Sears 2014, p. 6). He argues that individuals learn rapidly, but that it takes a collective effort and an infrastructure to "develop a big picture perspective on issues and to envision a better world worth fighting for" (Sears 2014, p. 6).

In our analysis of Venligboerne, the space for the civil society organization is expanded beyond a space for political protest. The solidarity work and the welcoming culture form part of a broader infrastructure of dissent. Venligboerne can be viewed as a community of collective learning, which is particularly pertinent at a time when refugees, migrants, and Muslims have been cast as the culprits of Europe's contemporary ailments. Here we see how learning becomes crucial for enacting everyday progressive politics. The movement's contributions are not merely protest actions against escalating political repression, but also an educational process focused on a renewed understanding of the other, whether the other is a refugee, unemployed, Muslim, migrant, or simply another Dane. Such learning processes are important in order to reorient the contemporary cultural trajectory that is moving us towards increasingly xenophobic, hierarchical, and self-centered outlooks on the world. While protest activity of course plays a part in the same direction, it is important to recognize the work of culturally oriented social activity that supports the protest activity by providing an open space for adult learning, and thus forms part of the infrastructures of dissent that enable contemporary formations of transformative alliances and possibilities for a reinvigoration of utopian politics of hope: the ability to collectively imagine better futures with space for a diverse range of subjectivities.

The experiential dimension of discovering possibilities of co-existence, shared ideas, possibilities for shared projects and cooperation, exchange and integration between different groups are all central aspects in understanding Venligboerne. From our analysis of Venligboerne, we argue that the organizational form in combination with the organizational goals provide a pertinent example of such a space for adult learning, which supports both engagement and interaction with a broad range of social organizations (Dewey 1916). 
Rather than focusing on the success or failure of such an approach (Haiven and Khasnabish 2016), it makes sense to view the praxis itself as a model for civil society activity. While the case here is obviously neither exclusive nor uniform, the point is less about a specific variety or type but about a general approach. While Venligboerne as a case provide a significant ensemble which we can learn much from, they should not be seen as the only possible configuration of such a CSO. In conclusion, in our work to improve on the social cohesion, solidarity, collaboration and general welfare of our societies, perhaps the most important issue is not to overlook the importance of everyday activism and adult learning as dimensions of CSO praxis and as parts of broader infrastructures of dissent.

\section{References}

Agustín, Ó. G., \& Jørgensen, M. B. (2016). Solidarity without borders: Gramscian perspectives on migration and civil society alliances. London: Pluto Press.

Agustín, Ó. G., \& Jørgensen, M. B. (2019). Solidarity and the refugee crisis in Europe. London: Palgrave Macmillan.

Anheier, H. (2004). Civil society: Measurement, evaluation, policy. London: Earthscan Publications.

Baumann, Z. (1999). In search of politics. Cambridge: Polity Press.

Beck, U. (2006). Magt og modmagt i den globale tidsalder. Copenhagen: Hans Reitzels Forlag.

Bloch, E. (1986). The principle of hope: Volume two. London: Basil Blackwell.

Carothers, T. (1999). Think again: Civil society. Foreign Policy. Available online at: http://carnegieendowment.org/pdf/CivilSociety.pdf

Dewey, J. (1916). Democracy and education. London: Free Press.

Dewey, J. (1938). The public and its problems: an essay in political inquiry. Ohio: Swallow Press.

Dubet, F. (1994). The system, the actor, and the social subject Thesis Eleven., 38, 16-35.

Fenger-Grøndahl, M. (2016). Venligboerne: Historien om en bevagelse. Copenhagen: Bibelselskabet.

Fominaya, C. F. (2010). Collective identity in social movements: Central concepts and debates. Sociology Compass, 4(6), 393-404.

Freire, P. (1970). Pedagogy of the oppressed. London: Penguin Books.

Giddens, A. (1991). Modernity and self identity: Self and society in the late modern age. Stanford: Stanford University Press.

Graeber, D. (2002). The new anarchists. New Left Review, 13, 61-74.

Haiven, M., \& Khasnabish, A. (2016). The radical imagination. London: Zed Books.

Jørgensen, M. B. (2016). Precariat - What it is and isn't - Toward an understanding of what it does. Critical Sociology, 42(7-8), 959-974.

Jørgensen, M. B., \& Agustín, Ó. G. (2015). The politics of dissent. In M. B. Jørgensen \& Ó. G. Agustín (Eds.), Politics of dissent: Political and social change (Vol. 1, pp. 11-25). Frankfurt am Main: Peter Lang.

Jørgensen, M. B., \& Thomsen, T. L. (2016). Deservingness in the Danish context: Welfare chauvinism in times of crisis. Critical Social Policy, 36(3), 330-351.

Kilgore, D. W. (1999). Understanding learning in social movements: A theory of collective learning. International Journal of Lifelong Education, 8(3), 191-202.

Lumholt, K. (2019). Kig på jeres frivillige - de er måske samfundsentreprenører.. Column from: http://www.kommunen.dk. Accessed 24 July 2019.

Marcello, M., \& Perrucci, R. (2000). Small groups and civic engagement: All about me? The Responsive Community: Rights and Responsibilities, 10(3), 67-73. 
Melucci, A. (1980). The new social movements: A theoretical approach. Social Science Information, 19(2), 199-226.

Mortensen, T., \& Lumholt, K. (2018). Fremtidens fallesskaber. Copenhagen: Selskabet for Fremtidsforskning.

Nygaard, M. (2017). Venligbogen. Copenhagen: Jensen \& Dalgaard.

Offe, C. (1985). New social movements: Challenging the boundaries of institutional politics. Social Research, 52(4), 817-868.

Piketty, T. (2018). Brahmin left vs. merchant right: Rising inequality \& the changing structure of political conflict (evidence from France, Britain and the US, 1948-2017). WID.world Working Paper Series, no. 2018/7.

Regeringen. (2010). National civilsamfundsstrategi: en styrket inddragelse af civilsamfundet og frivillige organisationer $i$ den sociale indsats. Copenhagen: Regerigen.

Regeringen. (2014). Den frivillige sociale indsats: frivillig rapport 2014. In Copenhagen: Center for Frivilligt Socialt Arbejde. Copenhagen: Regerigen.

Rutland, T. (2013). Activists in the Making: Urban Movements, Political Processes and the Creation of Political Subjects. International Journal of Urban and Regional Research, 37(3), 989-1011.

Sears, A. (2014). The next new left: A history of the future. Halifax/Winnipeg: Fernwood Publishing.

Staggenborg, S. (1988). The consequences of professionalization and formalization in the prochoice movement. American Sociological Review, 53, 585-605.

Thomsen, T., \& Jørgensen, M. B. (2013). Needed but undeserving: revisiting the liberal paradox. Recode. Working Paper Series, no. 32: 1-21.

Tilly, C. (1995). To explain political processes. American Journal of Sociology, 100, 1594-1610.

Toubøl, J. (2015). Septembermobiliseringen af flygtningesolidaritetsbevægelsen. Dansk Sociologi, 26(4), 96-103.

Toubøl, J. (2017). Differential recruitment to and outcomes of solidarity activism: Ethics, values and group style in the Danish refugee solidarity movement. $\mathrm{PhD}$ thesis University of Copenhagen.

TV2Nord. (2017, February 21). De frivillige. https://www.tv2nord.dk/de-frivillige/de-frivillige-38. Accessed 5 Nov 2019.

Venligboerne (n.d.). http://www.venligboerne.org/venligboernes-organisation/. Accessed 5 Nov 2019.

Welton, M. (1993). Social revolutionary learning: The new social movements as learning sites. Adult Education Quarterly, 43(3), 152-164.

Willem, J., \& Jeggers, M. (2012). Social movement structures in relation to goals and forms of action: an exploratory model. Canadian Journal of Nonprofit and Social Economy Research, $3(2), 67-81$.

Open Access This chapter is licensed under the terms of the Creative Commons Attribution 4.0 International License (http://creativecommons.org/licenses/by/4.0/), which permits use, sharing, adaptation, distribution and reproduction in any medium or format, as long as you give appropriate credit to the original author(s) and the source, provide a link to the Creative Commons license and indicate if changes were made.

The images or other third party material in this chapter are included in the chapter's Creative Commons license, unless indicated otherwise in a credit line to the material. If material is not included in the chapter's Creative Commons license and your intended use is not permitted by statutory regulation or exceeds the permitted use, you will need to obtain permission directly from the copyright holder.

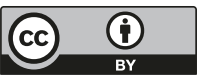

